\title{
EFFECT OF ORGANIC CULTIVATION ON THE OCCURRENCE OF BENEFICIAL GROUPS OF MICROORGANISMS IN THE RHIZOSPHERE SOIL OF VEGETABLE CROPS
}

\author{
Paweł TRZCIŃSKI*, Lidia Maria SAS-PASZT, Sławomir GŁUSZEK, Michał PRZYBYŁ, \\ Edyta DERKOWSKA \\ Research Institute of Horticulture \\ Konstytucji 3 Maja 1/3, 96-100 Skierniewice, Poland
}

Received: August 2016; Accepted: December 2018

\begin{abstract}
The article presents the results of research on the occurrence of beneficial groups of microorganisms in the rhizosphere of carrot, parsley and potato plants after the application of: (1) a commercial product EmFarma Plus (Probiotics Polska), (2) a consortium called Skierniewickie Microorganisms (MS) (containing three strains of Klebsiella oxytoca, Pseudomonas fluorescens, Pseudomonas sp.), and (3) Consortium MS together with EmFarma Plus. The study estimated the populations of microscopic fungi and bacteria, including the groups of microorganisms considered to be beneficial, i.e., spore-forming bacteria, fluorescent bacteria of the genus Pseudomonas, diazotrophs and actinomycetes. Applications of Consortium MS and, to a lesser extent, the preparation EmFarma Plus together with Consortium MS resulted in a significant increase in the total population of diazotrophs isolated from the rhizosphere soil of the vegetable species included in the study. There was no significant impact of the application of EmFarma Plus on the population size of the analyzed groups of microorganisms in the rhizosphere soil.
\end{abstract}

Keywords: PGPR, EmFarma Plus, carrot, parsley, potato

\section{INTRODUCTION}

Microorganisms play a significant role in soil and in agriculture, as they contribute to improvement of soil fertility by releasing nutrients into the soil through decomposition of organic matter, chelation/solubilization of inorganic compounds, and by fixation of nitrogen from the atmosphere. Another important role of soil microorganisms is their ability to affect plant growth and yielding. Some groups of microorganisms, like diazotrophs, fluorescent Pseudomonas, Bacillus spp. or Streptomyces spp., can have a positive influence on plant health and growth. The positive influence can be divided into two main effects: an increase in nutrient uptake by chelation/solubilization of elements or by sharing fixed nitrogen, and by a reduction of population sizes of soil-borne plant pathogens in the soil through competition for nutrients and living space, and/or antibiosis. Competition between microorganisms is the main factor limiting the occurrence of soil-borne pathogens, and is much stronger in soils with richer and more complex microbial diversity (Kennedy et al. 2005; Beatty \& Jensen 2002, Garrett 1970; Marschner 2012).

The use in agriculture of microorganisms that can increase the nutrition of plants and/or reduce the populations of pathogens in the environment can translate into increased crop yields while reducing mineral fertilization rates and the use of chemical plant protection products, and in some cases, completely replacing them (Keel et al. 1992; Kozyrovska et al. 1996; Canbolat et al. 2006).

Commercial preparations that have in their composition microorganisms for stimulating growth (Plant Growth Promoting Microorganisms PGPM) contain one or more strains of beneficial bacteria or fungi. Preparations that contain more 
than one beneficial strain are relatively rare because of the possibility of competition between the microorganisms in the soil, in the product, or during storage. On the other hand, preparations containing a wider range of suitably selected beneficial microorganisms can be more effective due to the synergistic action of the microorganisms or a greater range of their beneficial activity (Bashan 1998; do Vale Barreto Figueiredo et al. 2010).

The aim of the study was to evaluate the effect of preparations containing live microorganisms and organic fertilization on the size of populations of microscopic fungi and beneficial groups of bacteria in the rhizosphere soil of carrot, parsley and potato plants. The beneficial groups of bacteria were selected due to their important role in the soil: enhancing nutrient uptake by plants (i.e., fluorescent pseudomonads, diazotrophs), suppression of growth of pathogenic fungi (i.e., spore-forming bacteria, actinomycetes), and decomposition of organic matter (i.e., actinomycetes, spore-forming bacteria).

\section{MATERIAL AND METHODS}

The experiment was conducted in 2015 and 2016, on the EM AGRO PLUS Agri-Horticultural Farm in the Lódź province. The vegetable plants included in the experiment were carrot (Daucus carota) 'Laguna', parsley (Petroselinum crispum) 'Atika', and potato (Solanum tuberosum) 'Vineta'. The field experiment was set up in a randomized design with four plots per plant species, with an area of 0.025 ha for each parsley plot and 0.1 ha for each carrot and potato plot. The seeds of carrot and parsley were sown at a rate of 750,000-800,000 seeds per hectare, and the potato tubers were planted at a rate of 40,000-44,000 per hectare. In the autumns of 2014 and 2015, the soil of the experimental field was fertilized with cattle manure (at $30 \mathrm{t} \cdot \mathrm{ha}^{-1}$ ) and chicken manure (at $20 \mathrm{t} \cdot \mathrm{ha}^{-1}$ ). In 2015 and in 2016, before the seeds or potato tubers were planted, in the part of the field allocated for experimental combinations $2-5$, the following preparations were applied before sowing: EmFarma Plus (Probiotics Polska) at $10 \mathrm{dm}^{3} \cdot \mathrm{ha}^{-1}$, and humic acids HumiAgra (AgraPlant) at $1 \mathrm{~kg} \cdot \mathrm{ha}^{-1}$. During the emergence of plants (80-90\% germination), preparation AmiAgra
(AgraPlant) containing amino acids was applied at $200 \mathrm{~g} \cdot \mathrm{ha}^{-1}$. After the plants had formed leaves, organic nitrogen fertilizer Azocor (Fomet) (N $10.5 \%, \mathrm{P}-1.5 \%, \mathrm{~K}-1.5 \%, \mathrm{C}-82 \%$ ) was applied at $350 \mathrm{~kg} \cdot \mathrm{ha}^{-1}$. When the plants had reached the height of 15-20 cm, natural fertilizer Mikroplan Universal Max (Olimax) at $2 \mathrm{dm}^{3} \cdot \mathrm{ha}^{-1}$ and amino acids AmiAgra (Agra Plant) at $100 \mathrm{~g} \cdot \mathrm{ha}^{-1}$ were applied 3 times at 10-day intervals.

The chemical properties of the soils were determined in April 2015, at the start of the first year of the study, before the seeds or potato tubers were planted (Table 1). The bulk soil samples were collected according to the general rules for the sampling and transport of soil for analysis. Briefly: arable soil samples were collected with a soil sampler from a depth of 0-20 cm from twenty randomly selected sites. The thus prepared soil was treated with the microbiological preparations, 5 times at monthly intervals, from April to August during 2015 and 2016, using an agricultural sprayer adapted for vegetable crops.

The experiment included the following experimental combinations:

1. Untreated plants - plants growing in the soil with the addition of manure only, watered with water in the amount of $5 \times 400 \mathrm{dm}^{3} \cdot \mathrm{ha}^{-1}$.

2. Control - plants growing in the soil with the addition of manure and organic fertilizers, watered with water in the amount of $5 \times 400 \mathrm{dm}^{3} \cdot \mathrm{ha}^{-1}$.

3. EmFarma Plus (Probiotics Polska) - plants growing in the soil with the addition of manure and organic fertilizers and sprayed with $10 \%$ solution of EmFarma Plus in the amount of $5 \times$ $400 \mathrm{dm}^{3} \cdot \mathrm{ha}^{-1}$ (according to the manufacturer's recommendations). According to the producer, the preparation contains the following species: Bacillus subtilis var. natto, Bifidobacterium spp. (B. animalis, B. longum), Lactobacillus spp. (L. acidophilus, L. casei, L. delbrueckii ssp. bulgaricus, L. fermentum, L. plantarum), Lactococcus lactis ssp. lactis, Rhodopseudomonas spp. (R. palustris, R. sphaeroides), Streptococcus thermophilus, Saccharomyces cerevisiae (min. population size: $10^{7} \mathrm{cfu} \cdot \mathrm{ml}^{-1}$ ).

4. Consortium MS - plants growing in the soil with the addition of manure and organic fertilizers 
and sprayed with a consortium of Skierniewickie Microorganisms (MS) consisting of bacteria isolated and selected in the Rhizosphere Laboratory of the Research Institute of Horticulture in Skierniewice: Pseudomonas sp. SYMBIO BANK strain Pi22B, Pseudomonas fluorescens SYMBIO BANK strain Pi25C, Klebsiella oxytoca SYMBIO BANK strain NAzot2; applied by spraying with an aqueous solution of these bacteria in the amount of $5 \times 400 \mathrm{dm}^{3} \cdot \mathrm{ha}^{-1}$. The concentration of the bacteria in the solution was $1.5 \times 10^{7} \mathrm{cfu} \cdot \mathrm{ml}^{-1}$.

5. Consortium MS + EmFarma Plus plants growing in the soil with the addition of manure and organic fertilizers and sprayed with the amount of $5 \times 400 \mathrm{dm}^{3} \cdot \mathrm{ha}^{-1}$. The applied dose of EmFarma Plus was as in combination 2, and the concentration of MS was as in combination 3.

Rhizosphere soil for microbiological analyses was collected before the harvest on August $26^{\text {th }}$, 2015 and on September $1^{\text {st }}, 2016$ and subjected to microbiological analysis within a week. Briefly: roots with a thin layer of soil were delivered to the laboratory and placed in a refrigerator. Then, the rhizosphere soil was separated from the roots by gently shaking it off and/or scraping using sterile pipette tips. For the analysis, the amounts of approximately 10-20 g of rhizosphere soil were collected.

Table 1. Chemical properties of soils before the seeds or potato tubers were planted (EM AGRO PLUS Agri-Horticultural Farm 2015)

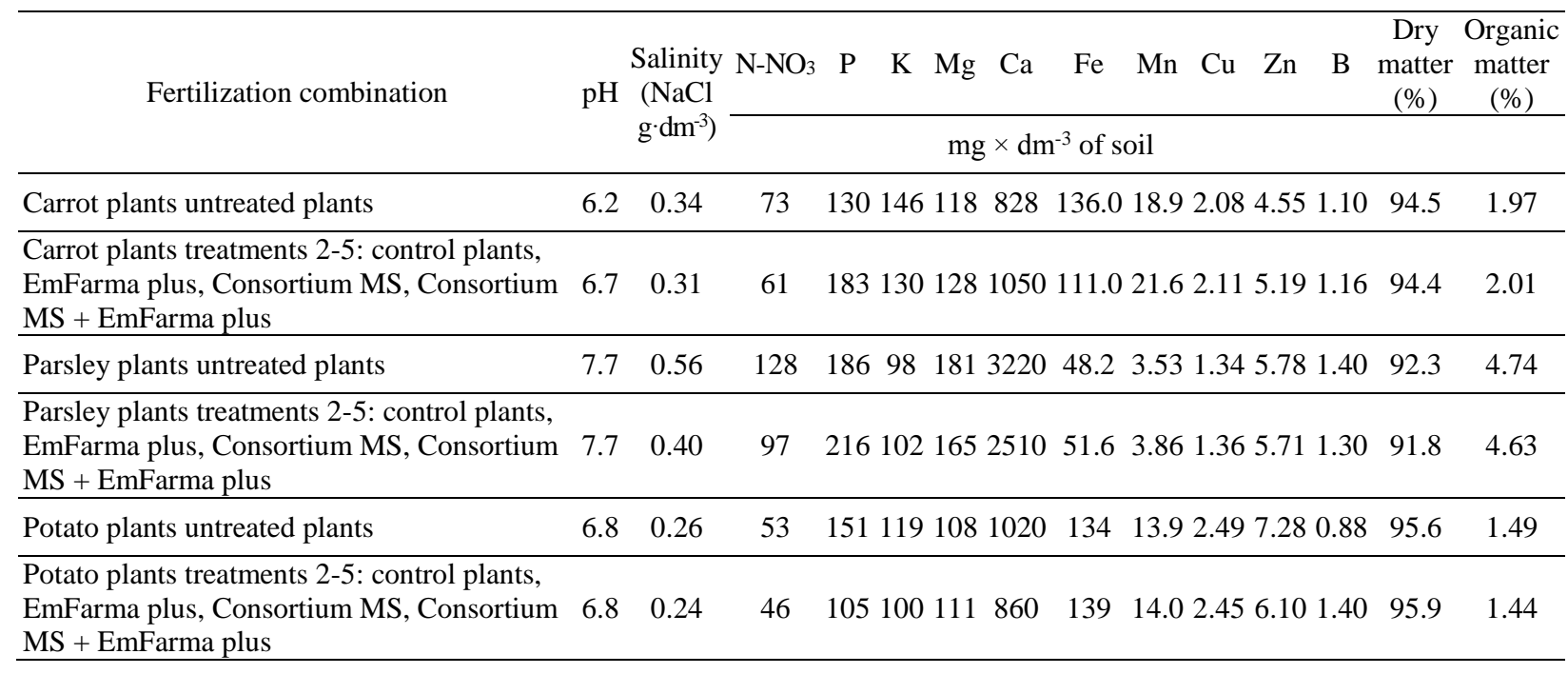

\section{Estimation of the number of microorganisms}

The rhizosphere soil samples were mixed and suspended in sterile distilled water at a ratio of $1: 9$. The suspensions were homogenized with a laboratory shaker for 45 minutes at the speed of 150 rates per minute. The homogenized suspensions were then used to prepare serial decimal dilutions $\left(10^{-2}\right.$, $10^{-3}, 10^{-4}, 10^{-5}, 10^{-6}$ ), which were used to inoculate the following culture media, depending on the parameter to be estimated: the total number of bacteria was estimated on $10 \%$ tryptic soy agar (TSA) (Ghyselinck et al. 2013); total number of filamentous fungi was estimated on Rose Bengal Chloramphenicol Agar (Ryckeboer et al. 2003); total number of actinomycetes was estimated on colloidal chitin agar (Hsu and Lockwood 1975) containing: dry colloidal chitin $4 \mathrm{~g}, \mathrm{~K}_{2} \mathrm{HPO}_{4} 0,7 \mathrm{~g}, \mathrm{KH}_{2} \mathrm{PO}_{4} 0.3 \mathrm{~g}$, $\mathrm{MgSO}_{4} \times 5 \mathrm{H}_{2} \mathrm{O} 0.5 \mathrm{~g}, \mathrm{FeSO}_{4} \times 7 \mathrm{H}_{2} \mathrm{O} 0.01 \mathrm{~g}$, $\mathrm{ZnSO}_{4} 0.001 \mathrm{~g}, \mathrm{MnCl}_{2} 0.001 \mathrm{~g}$, agar $20 \mathrm{~g}$, tap water $1000 \mathrm{~g}$, final $\mathrm{pH}-8$; total number of diazotrophs was estimated on Burk's medium (Kennedy et al. 2005) containing: $\mathrm{K}_{2} \mathrm{HPO}_{4} 0.64 \mathrm{~g}, \mathrm{KH}_{2} \mathrm{PO}_{4} 0.2 \mathrm{~g}$, $\mathrm{MgSO}_{4} \times 7 \mathrm{H}_{2} \mathrm{O} 0.2 \mathrm{~g}, \mathrm{NaCl} 0.2 \mathrm{~g}, \mathrm{CaSO}_{4} \times 2 \mathrm{H}_{2} \mathrm{O}$ $0.05 \mathrm{~g}, \mathrm{Na}_{2} \mathrm{MoO}_{4} 0.001 \mathrm{~g}, \mathrm{FeSO}_{4} 0.003 \mathrm{~g}$, mannitol $20 \mathrm{~g}$, agar $12 \mathrm{~g}$, distilled water $1000 \mathrm{~g}$; total number of fluorescent Pseudomonas bacteria was estimated on S1 medium (Gould et al. 1985) containing: sucrose $10 \mathrm{~g}$, glycerol $12.6 \mathrm{~g}$, casamino acids $5 \mathrm{~g}$, 
$\mathrm{NaHCO}_{3} 1 \mathrm{~g}, \mathrm{MgSO}_{4} \times 7 \mathrm{H}_{2} \mathrm{O} 1 \mathrm{~g}, \mathrm{~K}_{2} \mathrm{HPO}_{4} 2.3 \mathrm{~g}$, SLS $1.2 \mathrm{~g}$, trimethoprim $20 \mathrm{mg}$, agar $18 \mathrm{~g}$, distilled water $1000 \mathrm{~g}$; total number of spore-forming bacteria was estimated by incubating suspensions at $80{ }^{\circ} \mathrm{C}$ for 30 minutes and plating them on $10 \%$ tryptic soy agar.

Plates were incubated for 72 hours at $30{ }^{\circ} \mathrm{C}(\mathrm{S} 1$ and Burk's media), for $10-14$ days at $28^{\circ} \mathrm{C}(10 \%$ TSA, water agar), and for $5-7$ days at $25^{\circ} \mathrm{C}$ (Rose Bengal Chloramphenicol Agar). When calculating the number of microorganisms, only the plates on which the number of colonies fell within the range 30-300 were taken into consideration. The results were converted to colony-forming units per 1 gram of dry weight of medium ( $\left.\mathrm{cfu} \times \mathrm{g}^{-1} \mathrm{DW}\right)$. In order to express the number of microorganisms in terms of per $1 \mathrm{~g}$ of dry weight, samples of the media were dried at $105^{\circ} \mathrm{C}$ for 18 hours.

The microorganism populations were expressed as logarithms (base 10) of cfu (colony forming units) per gram of dry weight of the soil. The results (number of microorganisms) were subjected to one way ANOVA using Statistica version 10 (Statsoft Inc. 2012). Homogenous groups were determined with Tukey's test for $\mathrm{p}=0.05$.

\section{RESULTS}

Overall impact of microbiological preparations on the number of microorganisms in the rhizosphere soil of vegetable plants

The microbiological preparations had different effects on the population size of individual groups of microorganisms (Table 2). In the first year of the study, the use of combined Consortium MS and EmFarma Plus caused an increase in the population of spore-forming bacteria in the rhizosphere soil, in comparison with the control plants (Table 2). The use of EmFarma plus resulted in a decrease in the total number of bacteria, including diazotrophs. In the second year of the study, an increase in the spore-forming bacteria was observed in the rhizosphere soil of the plants treated with Consortium MS combined with EmFarma Plus, and the population of microscopic fungi was increased in the rhizosphere soil of the plants treated with EmFarma Plus, in comparison with the rhizosphere of the control plants (Table 2).

Effect of microbiological preparations on the number of microorganisms in the rhizosphere soil of carrot 'Laguna'

In the first year of the study, in comparison with the rhizosphere soil of the control plants, there was a significant increase in the number of diazotrophs after the application of Consortium MS alone and Consortium MS together with EmFarma Plus (Table 3). After the application of EmFarma Plus alone and Consortium MS combined with EmFarma Plus, an increase in the population of fluorescent bacteria of the genus Pseudomonas was observed, whereas application of Consortium MS alone resulted in a significant increase in the number of spore-forming bacteria (Table 3). In the second year of the study, there was a significant increase in the total number of bacteria, including spore-forming bacteria and diazotrophs, in the rhizosphere soil of the plants treated with Consortium MS combined with EmFarma Plus, and increased populations of diazotrophs and fluorescent Pseudomonads in the rhizosphere soil of the plants treated with Consortium MS, in comparison with the rhizosphere of the control plants. The population of microscopic fungi in the rhizosphere of the plants treated with EmFarma Plus was significantly increased, as compared to the rhizosphere of the control plants. The total number of actinomycetes decreased in the rhizosphere of untreated plants and after the application of Consortium MS, in comparison with the remaining treatments (Table 3). 
Table 2. Average population size of selected groups of microorganisms in the rhizosphere soil of vegetable plants, depending on the fertilization combination (EM AGRO PLUS Agri-Horticultural Farm 2015, 2016)

\begin{tabular}{|c|c|c|c|c|c|c|c|c|c|c|c|c|}
\hline \multirow{3}{*}{$\begin{array}{l}\text { Fertilization } \\
\text { combination }\end{array}$} & \multicolumn{12}{|c|}{ Population size of groups of microorganisms $\times \log _{10}\left(\mathrm{cfu} \cdot 1 \mathrm{~g}^{-1} \mathrm{DW}\right)$} \\
\hline & \multicolumn{2}{|c|}{ total bacteria } & \multicolumn{2}{|c|}{$\begin{array}{c}\text { spore-forming } \\
\text { bacteria }\end{array}$} & \multicolumn{2}{|c|}{$\begin{array}{c}\text { fluorescent Pseudo- } \\
\text { monas bacteria }\end{array}$} & \multicolumn{2}{|c|}{ diazotrophs } & \multicolumn{2}{|c|}{ actinomycetes } & \multicolumn{2}{|c|}{$\begin{array}{c}\text { microscopic } \\
\text { fungi }\end{array}$} \\
\hline & 2015 & 2016 & 2015 & 2016 & 2015 & 2016 & 2015 & 2016 & 2015 & 2016 & 2015 & 2016 \\
\hline Untreated plants & $7.3 \mathrm{ab}$ & $7.3 \mathrm{a}$ & $6.2 \mathrm{ab}$ & $6.2 \mathrm{~b}$ & $3.8 \mathrm{a}$ & $1.4 \mathrm{a}$ & $3.6 \mathrm{ab}$ & $6.1 \mathrm{a}$ & $5.3 \mathrm{a}$ & $6.5 \mathrm{a}$ & $4.9 \mathrm{a}$ & $4.8 \mathrm{ab}$ \\
\hline Control plants & $7.4 \mathrm{~b}$ & $7.4 \mathrm{a}$ & $6.2 \mathrm{a}$ & $6.1 \mathrm{ab}$ & $2.8 \mathrm{a}$ & $2.3 \mathrm{a}$ & $5.2 \mathrm{~b}$ & $5.9 \mathrm{a}$ & $5.5 \mathrm{a}$ & $6.6 \mathrm{a}$ & $4.9 \mathrm{a}$ & $4.7 \mathrm{a}$ \\
\hline EmFarma Plus & $7.1 \mathrm{a}$ & $7.4 \mathrm{a}$ & $6.2 \mathrm{a}$ & $6.1 \mathrm{a}$ & $2.4 \mathrm{a}$ & $2.7 \mathrm{a}$ & $1.8 \mathrm{a}$ & $5.9 \mathrm{a}$ & $5.6 \mathrm{a}$ & $6.5 \mathrm{a}$ & $4.8 \mathrm{a}$ & $5.0 \mathrm{~b}$ \\
\hline Consortium MS & $7.2 \mathrm{ab}$ & $7.3 \mathrm{a}$ & $6.3 \mathrm{ab}$ & $6.1 \mathrm{a}$ & $2.4 \mathrm{a}$ & $3.5 \mathrm{a}$ & $5.8 \mathrm{~b}$ & $6.2 \mathrm{a}$ & $5.7 \mathrm{a}$ & $6.6 \mathrm{a}$ & $4.8 \mathrm{a}$ & $4.6 \mathrm{a}$ \\
\hline $\begin{array}{l}\text { Consortium MS + } \\
\text { EmFarma Plus }\end{array}$ & $7.2 \mathrm{ab}$ & $7.4 \mathrm{a}$ & $6.4 \mathrm{~b}$ & $6.2 \mathrm{~b}$ & $3.8 \mathrm{a}$ & $2.4 \mathrm{a}$ & $5.6 \mathrm{~b}$ & $6.1 \mathrm{a}$ & $5.6 \mathrm{a}$ & $6.7 \mathrm{a}$ & $4.9 \mathrm{a}$ & $4.6 \mathrm{a}$ \\
\hline
\end{tabular}

Table 3. Population size of selected groups of microorganisms in the rhizosphere soil of carrot plants (EM AGRO PLUS Agri-Horticultural Farm 2015, 2016)

\begin{tabular}{|c|c|c|c|c|c|c|c|c|c|c|c|c|}
\hline \multirow{3}{*}{$\begin{array}{l}\text { Fertilization } \\
\text { combination }\end{array}$} & \multicolumn{12}{|c|}{ Population size of groups of microorganisms $\times \log _{10}\left(\mathrm{cfu} \cdot 1 \mathrm{~g}^{-1} \mathrm{DW}\right)$} \\
\hline & \multicolumn{2}{|c|}{ total bacteria } & \multicolumn{2}{|c|}{$\begin{array}{c}\text { spore-forming } \\
\text { bacteria }\end{array}$} & \multicolumn{2}{|c|}{$\begin{array}{c}\text { fluorescent Pseudo- } \\
\text { monas bacteria }\end{array}$} & \multicolumn{2}{|c|}{ diazotrophs } & \multicolumn{2}{|c|}{ actinomycetes } & \multicolumn{2}{|c|}{$\begin{array}{l}\text { microscopic } \\
\text { fungi }\end{array}$} \\
\hline & 2015 & 2016 & 2015 & 2016 & 2015 & 2016 & 2015 & 2016 & 2015 & 2016 & 2015 & 2016 \\
\hline Untreated plants & $7.2 \mathrm{~b}$ & $7.5 \mathrm{~b}$ & $6.4 \mathrm{~b}$ & $6.2 \mathrm{~b}$ & $3.5 \mathrm{bc}$ & $0 * \mathrm{a}$ & $0 * \mathrm{a}$ & $6.5 \mathrm{~b}$ & $5.9 \mathrm{a}$ & $6.6 \mathrm{a}$ & $4.9 \mathrm{a}$ & $4.8 \mathrm{~b}$ \\
\hline Control plants & $7.1 \mathrm{ab}$ & $7.1 \mathrm{a}$ & $6.3 \mathrm{ab}$ & $6.2 \mathrm{~b}$ & $0 * \mathrm{a}$ & $0 * \mathrm{a}$ & $5.0 \mathrm{~b}$ & $6.3 \mathrm{a}$ & $5.9 \mathrm{a}$ & $6.7 \mathrm{~b}$ & $4.9 \mathrm{a}$ & $4.6 \mathrm{a}$ \\
\hline EmFarma Plus & $7.1 \mathrm{a}$ & $7.2 \mathrm{a}$ & $6.3 \mathrm{a}$ & $6.0 \mathrm{a}$ & $3.3 \mathrm{~b}$ & $0 * \mathrm{a}$ & $0 * \mathrm{a}$ & $6.5 \mathrm{ab}$ & $5.9 \mathrm{a}$ & $6.7 \mathrm{~b}$ & $4.8 \mathrm{a}$ & $4.9 \mathrm{~b}$ \\
\hline Consortium MS & $7.2 \mathrm{~b}$ & $7.1 \mathrm{a}$ & $6.5 \mathrm{c}$ & $6.0 \mathrm{a}$ & $0 * a$ & $3.7 \mathrm{~b}$ & $6.1 \mathrm{c}$ & $6.6 \mathrm{~b}$ & $5.9 \mathrm{a}$ & $6.6 \mathrm{a}$ & $4.9 \mathrm{a}$ & $4.6 \mathrm{a}$ \\
\hline $\begin{array}{l}\text { Consortium MS + } \\
\text { EmFarma Plus }\end{array}$ & $7.1 \mathrm{ab}$ & $7.5 \mathrm{~b}$ & $6.4 \mathrm{~b}$ & $6.4 \mathrm{c}$ & $3.6 \mathrm{c}$ & $0 * a$ & $5.9 \mathrm{c}$ & $6.5 \mathrm{~b}$ & $5.9 \mathrm{a}$ & $6.8 \mathrm{~b}$ & $4.8 \mathrm{a}$ & $4.7 \mathrm{a}$ \\
\hline
\end{tabular}

Results of microbiological analyses verified with univariate analysis of variance using Statistica 10. Homogenous groups determined with HSD test for $\mathrm{p}=0.05$.

* below detection limit

Effect of microbiological preparations on the number of microorganisms in the rhizosphere soil of parsley 'Atika'

In the first year of the study, in comparison with the rhizosphere soil of the control plants, there was a significant increase in the number of diazotrophs after the application of Consortium MS (Table 4). In the second year, there were higher populations of diazotrophs and microscopic fungi in the rhizosphere soil of the plants treated with EmFarma Plus and an increased population of actinomycetes and microscopic fungi in the rhizosphere soil of the plants treated with Consortium MS combined with EmFarma Plus, in comparison with the rhizosphere soil of the control plants (Table 4).
Effect of microbiological preparations on the number of microorganisms in the rhizosphere soil of potato 'Vineta'

In the first year of the study, in comparison with the rhizosphere soil of the control plants, the use of microbiological preparations decreased the total number of bacteria, including the populations of fluorescent bacteria of the genus Pseudomonas (Table 5). After the application of Consortium MS, there was a significant increase in the number of actinomycetes, while the rhizosphere of potato plants treated with Consortium MS in combination with EmFarma Plus was colonized by larger populations of spore-forming bacteria and microscopic fungi, compared to the rhizosphere of the control plants 
(Table 5). In the second year of the study, there were significantly higher populations of diazotrophs after the use of Consortium MS and Consortium MS applied together with EmFarma Plus, and a higher number of microscopic fungi after the use of EmFarma Plus, in comparison with the rhizosphere of the control plants (Table 5). The use of Consortium MS and Consortium MS combined with EmFarma Plus significantly decreased the total number of bacteria and microscopic fungi in the rhizosphere soil, in comparison with the rhizosphere of the control plants (Table 5).

Table 4. Population size of selected groups of microorganisms in the rhizosphere soil of parsley plants (EM AGRO PLUS Agri-Horticultural Farm 2015, 2016)

\begin{tabular}{|c|c|c|c|c|c|c|c|c|c|c|c|c|}
\hline \multirow{3}{*}{$\begin{array}{l}\text { Fertilization } \\
\text { combination }\end{array}$} & \multicolumn{12}{|c|}{ Population size of groups of microorganisms $\times \log 10\left(\mathrm{cfu} \cdot 1 \mathrm{~g}^{-1} \mathrm{DW}\right)$} \\
\hline & \multicolumn{2}{|c|}{ total bacteria } & \multicolumn{2}{|c|}{$\begin{array}{l}\text { spore-forming } \\
\text { bacteria }\end{array}$} & \multicolumn{2}{|c|}{$\begin{array}{c}\text { fluorescent } P \text { seudo- } \\
\text { monas bacteria }\end{array}$} & \multicolumn{2}{|c|}{ diazotrophs } & \multicolumn{2}{|c|}{ actinomycetes } & \multicolumn{2}{|c|}{$\begin{array}{c}\text { microscopic } \\
\text { fungi }\end{array}$} \\
\hline & 2015 & 2016 & 2015 & 2016 & 2015 & 2016 & 2015 & 2016 & 2015 & 2016 & 2015 & 2016 \\
\hline Untreated plants & $7.2 \mathrm{a}$ & $7.3 \mathrm{a}$ & $6.2 \mathrm{a}$ & $6.3 \mathrm{~b}$ & $3.5 \mathrm{~b}$ & $0 * \mathrm{a}$ & $5.4 \mathrm{c}$ & $5.7 \mathrm{c}$ & $4.3 \mathrm{a}$ & $6.5 \mathrm{ab}$ & $4.7 \mathrm{a}$ & $5.2 \mathrm{c}$ \\
\hline Control plants & $7.3 \mathrm{a}$ & $7.5 \mathrm{bc}$ & $6.2 \mathrm{a}$ & $6.0 \mathrm{a}$ & $3.5 \mathrm{~b}$ & $3.2 \mathrm{~b}$ & $5.2 \mathrm{bc}$ & $5.6 \mathrm{bc}$ & $4.9 \mathrm{~b}$ & $6.5 \mathrm{~b}$ & $4.7 \mathrm{a}$ & $4.6 \mathrm{a}$ \\
\hline EmFarma Plus & $7.3 \mathrm{a}$ & $7.5 \mathrm{c}$ & $6.2 \mathrm{a}$ & $6.1 \mathrm{a}$ & $0 * \mathrm{a}$ & $4.4 \mathrm{~b}$ & $0 * \mathrm{a}$ & $5.8 \mathrm{~d}$ & $5.1 \mathrm{~b}$ & $6.5 \mathrm{ab}$ & $4.7 \mathrm{a}$ & $4.8 \mathrm{~b}$ \\
\hline Consortium MS & $7.2 \mathrm{a}$ & $7.4 \mathrm{ab}$ & $6.3 \mathrm{a}$ & $6.0 \mathrm{a}$ & $3.7 \mathrm{~b}$ & $3.5 \mathrm{~b}$ & $5.7 \mathrm{~d}$ & $5.5 \mathrm{ab}$ & $5.4 \mathrm{c}$ & $6.4 \mathrm{a}$ & $4.7 \mathrm{a}$ & $4.5 \mathrm{a}$ \\
\hline $\begin{array}{l}\text { Consortium MS + } \\
\text { EmFarma Plus }\end{array}$ & $7.3 \mathrm{a}$ & $7.5 \mathrm{bc}$ & $6.3 \mathrm{a}$ & $6.2 \mathrm{a}$ & $3.8 \mathrm{~b}$ & $3.6 \mathrm{~b}$ & $5.1 \mathrm{~b}$ & $5.4 \mathrm{a}$ & $5.1 \mathrm{bc}$ & $6.7 \mathrm{c}$ & $4.8 \mathrm{a}$ & $4.7 \mathrm{~b}$ \\
\hline
\end{tabular}

Note: see Table 3

Table 5. Population size of selected groups of microorganisms in the rhizosphere soil of potato plants (EM AGRO PLUS Agri-Horticultural Farm 2015, 2016)

\begin{tabular}{|c|c|c|c|c|c|c|c|c|c|c|c|c|}
\hline \multirow{3}{*}{$\begin{array}{l}\text { Fertilization } \\
\text { combination }\end{array}$} & \multicolumn{12}{|c|}{ Population size of groups of microorganisms $\times \log _{10}\left(\mathrm{cfu} \cdot 1 \mathrm{~g}^{-1} \mathrm{DW}\right)$} \\
\hline & \multicolumn{2}{|c|}{ total bacteria } & \multicolumn{2}{|c|}{$\begin{array}{c}\text { spore-forming } \\
\text { bacteria }\end{array}$} & \multicolumn{2}{|c|}{$\begin{array}{c}\text { fluorescent Pseudo- } \\
\text { monas bacteria }\end{array}$} & \multicolumn{2}{|c|}{ diazotrophs } & \multicolumn{2}{|c|}{ actinomycetes } & \multicolumn{2}{|c|}{$\begin{array}{l}\text { microscopic } \\
\text { fungi }\end{array}$} \\
\hline & 2015 & 2016 & 2015 & 2016 & 2015 & 2016 & 2015 & 2016 & 2015 & 2016 & 2015 & 2016 \\
\hline & $7.7 \mathrm{c}$ & $7.2 \mathrm{a}$ & $6.1 \mathrm{a}$ & $6.2 \mathrm{a}$ & $4.6 \mathrm{c}$ & $3.3 \mathrm{a}$ & $5.5 \mathrm{ab}$ & $6.2 \mathrm{c}$ & $5.7 \mathrm{a}$ & $6.5 \mathrm{a}$ & $5.1 \mathrm{c}$ & $4.3 \mathrm{a}$ \\
\hline Control plants & $7.7 \mathrm{c}$ & $7.5 \mathrm{~b}$ & $6.1 \mathrm{a}$ & $6.2 \mathrm{a}$ & $4.9 \mathrm{c}$ & $3.5 \mathrm{a}$ & $5.5 \mathrm{ab}$ & $5.7 \mathrm{~b}$ & $5.7 \mathrm{a}$ & $6.6 \mathrm{ab}$ & $4.9 \mathrm{~b}$ & $4.8 \mathrm{c}$ \\
\hline EmFarma Plus & $7.0 \mathrm{a}$ & $7.4 \mathrm{~b}$ & $6.1 \mathrm{a}$ & $6.1 \mathrm{a}$ & $4.0 \mathrm{~b}$ & $3.8 \mathrm{a}$ & $5.4 \mathrm{a}$ & $5.5 \mathrm{a}$ & $5.7 \mathrm{a}$ & $6.4 \mathrm{ab}$ & $4.8 \mathrm{a}$ & $5.2 \mathrm{~d}$ \\
\hline Consortium MS & $7.3 \mathrm{~b}$ & $7.2 \mathrm{a}$ & $6.1 \mathrm{a}$ & $6.2 \mathrm{a}$ & $3.3 \mathrm{a}$ & $3.4 \mathrm{a}$ & $5.5 \mathrm{ab}$ & $6.4 \mathrm{~d}$ & $5.9 \mathrm{~b}$ & $6.6 \mathrm{ab}$ & $4.8 \mathrm{ab}$ & $4.6 \mathrm{~b}$ \\
\hline $\begin{array}{l}\text { Consortium MS + } \\
\text { EmFarma Plus }\end{array}$ & $7.3 \mathrm{~b}$ & $7.2 \mathrm{a}$ & $6.5 \mathrm{~b}$ & $6.2 \mathrm{a}$ & $3.9 \mathrm{~b}$ & $3.7 \mathrm{a}$ & $5.6 \mathrm{~b}$ & $6.4 \mathrm{~d}$ & $5.7 \mathrm{a}$ & $6.5 \mathrm{~b}$ & $5.1 \mathrm{c}$ & $4.4 \mathrm{ab}$ \\
\hline
\end{tabular}

Note: see Table 3

\section{DISCUSSION}

The effectiveness of applied microbial inocula to enhance plant growth or to control a population of plant pathogens is strictly limited by environmental and human-dependent factors. One of the most significant factors related to effectiveness of using microbial preparations is the dosage. Due to the economic limitation, the dosage of commercial inocula, depending on the formulation, usually amounts to several kilograms or liters per hectare. On the other hand, the estimated amount of soil microorganisms according to different authors varies from 0.4 to $15 \mathrm{Mg}$ per hectare (Schaechter 2004; Libudzisz et al. 2009). Considering that the amount of microbial biomass in commercial preparations is below part per thousand of total mass of the product, the number of applied microorganisms represents a tiny percentage of the overall population of soil bacteria and fungi. Other important factors limiting 
the effectiveness of microbial inocula is the competition for food sources and living space from microorganisms dwelling in the soil (Gunalan \& Fournier 1993; van Elsas et al. 2011), soil moisture and temperature (Borowik \& Wyszkowska 2016), pH (van Elsas \& van Overbeek 1993), availability of nutrients and texture of the soil (van Elsas et al. 1986; Acea \& Alexander 1988) or used microbial carrier (van Dyke \& Prosser 2000). Due to the fact that environmental factors could change between vegetation seasons, the stable positive effects of applied bacteria or fungi in several sequent seasons are seldom. For example, the studies of the impact of $\mathrm{AzO}$ tobacter species on various plant species was widely studied in the Soviet Union and in Egypt between 1950 and 1970. Although some positive effects were observed, due to the inconsistency of results, the practical inoculation of the crops has been abandoned (Kennedy et al. 2005). The consortium of Skierniewickie Microorganisms used in this experiment had a positive impact on increasing the population of diazotrophs in the rhizosphere of carrot plants in 2015 and 2016. The number of diazotrophs in the rhizosphere of parsley and potato plants increased after the use of Consortium MS; however, the obtained changes in the population of diazotrophs varied depending on the year of the study. The observed increase in the population of diazotrophs after 30 days from the last application of Consortium MS could be connected with the survival of Klebsiella oxytoca in the rhizosphere. The survival rate of transformed cells of Klebsiella oxytoca (strain VN13) in the rhizosphere of barley roots was estimated by Kozyrovska et al. (1994) and ranged from 14 days to more than 4 months. Results of the experiments with this species cannot be fully compared with others because there are very limited data in the literature on the use of this bacterium for stimulating the growth of vegetable plants and its survivability in the soil.

Applications of Consortium MS did not increase the number of fluorescent bacteria of the genus Pseudomonas, which may have been associated with different environmental factors. Reports of other authors on the survival of bacteria of the genus Pseudomonas have shown that their populations can be reduced already after 10-14 days after application, and can be dependent on, among others, the temperature (Loper et al. 1985; Davies \& Whitbread 1989; Schmidt et al. 2004), plant species (Latour et al. 1996), or the type of soil (Van Overbeek et al. 1995; Latour et al. 1996). Another factor able to affect the number of applied bacteria of the genus Pseudomonas may have been competition from other microorganisms inhabiting the rhizosphere. The impact of competition between microorganisms for nutrients and ecological niche on the population of microorganisms inhabiting the soil have been studied by Elad and Chet (1987), Hibbing et al. (2010) and Garrett (1970), among others.

Combining Consortium MS with the EM preparation did not produce an improvement in the results compared to the results obtained after the application of Consortium MS alone, which allows the conclusion that the use of both preparation together is ineffective. Research conducted in Poland and around the world does not provide conclusive results on the effect of the preparations based on "Effective Microorganisms" on the population size and activity of microorganisms inhabiting cultivated soils (Okorski \& Majchrzak 2007; Schenck zu Schweinsberg-Mickan \& Müller 2009; Mayer et al. 2010; Wolna-Maruwka et al. 2010; Wolna-Maruwka \& Gajewski 2011; Kordas \& Zbroszczyk 2012). In the studies by Wolna-Maruwka et al. (2010), the use of an EM preparation derived from the experimental farm of the University of Life Sciences in Poznań, increased the number of bacteria, including actinomycetes, in the soil, with a concomitant reduction in the occurrence of mold fungi. These data are not in agreement with our results because these effects were not noticed in our studies. However, the differences in the results could be explained by the different plant species used in our experiment, or by environmental factors, like the soil type.

The results of this study indicate the need for further and detailed research, using molecular techniques for detection of applied beneficial microorganisms and on the influence of microbiological preparations on the activity of microflora in the rhizosphere soil of crop plants. The observed differ- 
ences in the number of microorganisms in the rhizosphere of carrot, parsley and potato could be connected with biotic factors like different host plants and types of root exudates, or abiotic factors including chemical properties of the soil (Table 1). Similar differences are common and were reported by Grayston et al. (1998), Wieland et al. (2001), Innes et al. (2004), Batten et al. (2006), Broeckling et al. (2008), Nakhro and Dkhar (2010). The effect of organic fertilization in our experiment on the population size of the studied groups of microorganisms was small, which was probably related to the high abundance in the soil of nutrients from the fertilization with manure. The effect of fertilization on increasing the populations of bacteria and fungi in the soil is well-known and has been reported many times by Edesi et al. (2013), Zhen et al. (2014), Tamilselvi et al. (2015) and others.

The observed differences in analyzed groups of microorganisms between seasons of 2015 and 2016 could be associated with different environmental factors like the temperature and moisture of the soil. According to the data from the Institute of Meteorology and Water Management - National Research Institute (http://www.imgw.pl/projekty_programy/klimat/), the mean temperature in 2015 was slightly higher $\left(20^{\circ} \mathrm{C}\right)$ and the total precipitation was lower $(80$ $100 \mathrm{~mm})$ in comparison with $2016\left(19{ }^{\circ} \mathrm{C}\right.$ and 200 $220 \mathrm{~mm}$ ). Effects of soil temperature and moisture on microbial population and activity were studied, for example, by Cho et al. (2008) and Mayer et al. (2010).

\section{CONCLUSIONS}

1. Application of the consortium of Skierniewickie Microorganisms (MS) resulted in an increase in the population of diazotrophs in the rhizosphere of carrot, parsley and potato plants.

2. Combined application of the consortium of Skierniewickie Microorganisms with the preparation EmFarma Plus contributed to an increase in the population of diazotrophs in the rhizosphere of carrot plants.

3. The results indicate a lack of synergy in the interaction of Skierniewickie Microorganisms with the preparation EmFarma Plus.

\section{REFERENCES}

Acea M.J., Alexander M. 1988. Growth and survival of bacteria introduced into carbon-amended soil. Soil Biology and Biochemistry 20(5): 703-709. DOI: 10.1016/0038-0717(88)90155-1.

Bashan Y. 1998. Inoculants of plant growth-promoting bacteria for use in agriculture. Biotechnology Advances 16(4): 729-770. DOI: 10.1016/s07349750(98)00003-2.

Batten K.M., Scow K.M., Davies K.F., Harrison S.P. 2006. Two invasive plants alter soil microbial community composition in serpentine grasslands. Biological Invasions 8(2): 217-230. DOI: 10.1007/s10530-004-3856-8.

Beatty P.H., Jensen S.E. 2002. Paenibacillus polymyxa produces fusaricidin-type antifungal antibiotics active against Leptosphaeria maculans, the causative agent of blackleg disease of canola. Canadian Journal of Microbiology 48(2): 159-169. DOI: 10.1139/w02-002.

Borowik A., Wyszkowska J. 2016. Soil moisture as a factor affecting the microbiological and biochemical activity of soil. Plant, Soil and Environment 62(6): 250-255. DOI: 10.17221/158/2016-pse.

Broeckling C.D., Broz A.K., Bergelson J., Manter D.K., Vivanco J.M. 2008. Root exudates regulate soil fungal community composition and diversity. Applied and Environmental Microbiology 74(3): 738744. DOI: 10.1128/aem.02188-07.

Canbolat M.Y., Barik K., Çakmakçi R., Şahin F. 2006. Effects of mineral and biofertilizers on barley growth on compacted soil. Acta Agriculturae Scandinavica, Section B - Plant Soil Science 56: 324332. DOI: 10.1080/09064710600591067.

Cho S.-T., Tsai S.-H., Ravindran A., Selvam A., Yang S.-S. 2008. Seasonal variation of microbial populations and biomass in Tatachia grassland soils of Taiwan. Environmental Geochemistry and Health 30(3): 255-272. DOI: 10.1007/s10653-007-9113-1.

Davies K.G., Whitbread R. 1989. Factors affecting the colonisation of a root system by fluorescent Pseudomonads: The effects of water, temperature and soil microflora. Plant and Soil 116(2): 247-256. DOI: $10.1007 / \mathrm{bf02214554.}$

Edesi L., Järvan M., Lauringson E., Akk E., Tamm K. 2013. The effect of solid cattle manure on soil microbial activity and on plate count microorganisms in organic and conventional farming systems. International Journal of Current Microbiology and Applied Sciences 2(12): 476-488. 
Elad Y., Chet I. 1987. Possible role of competition for nutrients in biocontrol of Pythium damping-off by bacteria. Phytopathology 77: 190-195. DOI: 10.1094/phyto-77-190.

van Elsas J.D., Dijkstra A.F., Govaert J.M., van Veen J.A. 1986. Survival of Pseudomonas fluorescens and Bacillus subtilis introduced into two soils of different texture in field microplots. FEMS Microbiology Letters 38(3): 151-160. DOI: 10.1111/j.1574-6968.1986.tb01724.x.

van Elsas J.D., van Overbeek L.S. 1993. Bacterial responses to soil stimuli. In: Kjelleberg S. (Ed.), Starvation in bacteria. Springer, USA, pp. 55-79. DOI: 10.1007/978-1-4899-2439-1_3.

van Elsas J.D., Semenov A.V., Costa R., Trevors J.T. 2011. Survival of Escherichia coli in the environment: fundamental and public health aspects. ISME Journal 5(2): 173-183. DOI: 10.1038/ismej.2010.80.

Garrett S.D. 1970. Pathogenic Root-Infecting Fungi. Cambridge University Press, UK, 294 p.

Ghyselinck J., Velivelli S.L.S., Heylen K., O’Herlihy E., Franco J., Rojas M., De Vos P., Doyle Prestwich B. 2013. Bioprospecting in potato fields in the Central Andean Highlands: Screening of rhizobacteria for plant growth-promoting properties. Systematic and Applied Microbiology 36: 116-127. DOI: 10.1016/j.syapm.2012.11.007.

Gould W.D., Hagedorn C., Bardinelli T.R., Zablotowicz R.M. 1985. New selective media for enumeration and recovery of fluorescent pseudomonads from various habitats. Applied and Environmental Microbiology 49: 28-32.

Grayston S.J., Wang S., Campbell C.D., Edwards A.C. 1998. Selective influence of plant species on microbial diversity in the rhizosphere. Soil Biology and Biochemistry 30(3): 369-378. DOI: 10.1016/s0038-0717(97)00124-7.

Gunalan, Fournier J.C. 1993. Effect of microbial competition on the survival and activity of 2,4-D-degrading Alcaligenes xylosoxidans subsp. denitrificans added to soil. Letters in Applied Microbiology 16: 178 181. DOI: 10.1111/j.1472-765x.1993.tb01389.x.

Hibbing M.E., Fuqua C., Parsek M.R., Peterson S.B. 2010. Bacterial competition: surviving and thriving in the microbial jungle. Nature Reviews Microbiology 8(1): 15-25. DOI: 10.1038/nrmicro2259.

Hsu S.C., Lockwood J.L. 1975. Powdered chitin agar as a selective medium for enumeration of actinomycetes in water and soil. Applied Microbiology 29: 422-426.

Innes L., Hobbs P.J., Bardgett R.D. 2004. The impacts of individual plant species on rhizosphere microbial communities in soils of different fertility. Biology and Fertility of Soils 40(1): 7-13. DOI: 10.1007/s00374-004-0748-0.

Keel C., Schnider U., Maurhofer M., Voisard C., Laville J., Burger U. et al. 1992. Suppression of root diseases by Pseudomonas fluorescens $\mathrm{CHA0}$ : Importance of the bacterial secondary metabolite 2,4-diacetylphloroglucinol. Molecular Plant-Microbe Interactions 5(1): 4-13. DOI: 10.1094/mpmi-5-004.

Kennedy C., Rudnick P., MacDonald M.L., Melton T. 2005. Genus Azotobacter. In: Garrity G.M. (Ed.), Bergey's Manual of Systematic Bacteriology, vol. $2 b, 2^{\text {nd }}$ ed. Springer, USA, pp. 394-395.

Kordas L., Zbroszczyk U. 2012. The effect of tillage and effective microorganisms (EM) application on biological soil properties of spring wheat growing in short-term monoculture. Fragmenta Agronomica 29(3): 95-102. [in Polish with English abstract]

Kozyrovska N.A., Alexeyev M.F., Kovtunovich G.L., Gun'kovska N.V., Kordyum V.A. 1994. Bioluminescence-based detection of Klebsiella oxytoca VN13 in the environment. Biopolymers and Cell 10(2): 17-23. DOI: 10.7124/bc.00039d.

Kozyrovska N., Kovtunovych G., Gromosova E., Kuharchuk P., Kordyum V. 1996. Novel inoculants for an environmentally-friendly crop production. Resources, Conservation and Recycling 18: 79-85. DOI: 10.1016/s0921-3449(96)01170-6.

Latour X., Corberand T., Laguerre G., Allard F., Lemanceau P. 1996. The composition of fluorescent pseudomonad populations associated with roots is influenced by plant and soil type. Applied and Environmental Microbiology 62(7): 2449-2456.

Libudzisz Z., Kowal K., Żakowska Z. 2009. Mikrobiologia techniczna, vol. 1. PWN, 193 p. [in Polish]

Loper J.E., Haack C., Schroth M.N. 1985. Population dynamics of soil pseudomonads in the rhizosphere of potato (Solanum tuberosum L.). Applied and Environmental Microbiology 49(2): 416-422.

Marschner P. 2012. Marschner's Mineral Nutrition of Higher Plants, $3^{\text {rd }}$ ed. Elsevier, 672 p. DOI: 10.1016/c2009-0-63043-9.

Mayer J., Scheid S., Widmer F., Fließbach A., Oberholzer H.R. 2010. How effective are 'Effective microorganisms $^{\circledR}(\mathrm{EM}) '$ ? Results from a field study in temperate climate. Applied Soil Ecology 46: 230 239. DOI: 10.1016/j.apsoil.2010.08.007.

Nakhro N., Dkhar M.S. 2010. Impact of organic and inorganic fertilizers on microbial populations and biomass carbon in paddy field soil. Journal of Agronomy 9: 102-110. DOI: 10.3923/ja.2010.102.110. 
Okorski A., Majchrzak B. 2007. Fungi isolated from soil before the seeding and after harvest of pea (Pisum sativum L.) after application of bio-control product EM 1. Acta Agrobotanica 60: 113-121. DOI: 10.5586/aa.2007.014.

van Overbeek L.S., Eberl L., Givskov M., Molin S., van Elsas J.D. 1995. Survival of, and induced stress resistance in, carbon-starved Pseudomonas fluorescens cells residing in soil. Applied and Environmental Microbiology 61(12): 4202-4208.

Ryckeboer J., Mergaert J., Coosemans J., Deprins, K. Swings J. 2003. Microbiological aspects of biowaste during composting in a monitored compost bin. Journal of Applied Microbiology 94: 127-137. DOI: 10.1046/j.1365-2672.2003.01800.x.

Schaechter M. 2004. The Desk Encyclopedia of Microbiology. Elsevier, pp. 916.

Schenck zu Schweinsberg-Mickan M., Müller T. 2009. Impact of effective microorganisms and other biofertilizers on soil microbial characteristics, organicmatter decomposition, and plant growth. Journal of Plant Nutrition and Soil Science 172: 704-712. DOI: 10.1002/jpln.200800021.

Schmidt S.K., Lipson D.A., Ley R.E., Fisk M.C., West A.E. 2004. Impacts of chronic nitrogen additions vary seasonally and by microbial functional group in tundra soils. Biogeochemistry 69(1): 1-17. DOI: 10.1023/b:biog.0000031028.53116.9b.

Tamilselvi S.M., Chinnadurai C., Ilamurugu K., Arulmozhiselvan K., Balachandar D. 2015. Effect of long-term nutrient managements on biological and biochemical properties of semi-arid tropical Alfisol during maize crop development stages. Ecological Indicators 48: 76-87. DOI: 10.1016/j.ecolind.2014.08.001. do Vale Barreto Figueiredo M., Seldin L., de Araujo F.F., de Lima Ramos Mariano R. 2010. Plant growth promoting rhizobacteria: fundamentals and applications. Microbiology Monographs 18: 21-43. DOI: 10.1007/978-3-642-13612-2_2.

Van Dyke M.I., Prosser J.I. 2000. Enhanced survival of Pseudomonas fluorescens in soil following establishment of inoculum in a sterile soil carrier. Soil Biology and Biochemistry 32(10): 1377-1382. DOI: 10.1016/s0038-0717(00)00055-9.

Wieland G., Neumann R., Backhaus H. 2001. Variation of microbial communities in soil, rhizosphere, and rhizoplane in response to crop species, soil type, and crop development. Applied and Environmental Microbiology 67(12): 5849-5854. DOI: 10.1128/aem.67.12.5849-5854.2001.

Wolna-Maruwka A., Schroeter-Zakrzewska A., Borowiak K. 2010. Effect of EM inoculum on the microbiological state of substrate designed for pelargonium (Pelargonium $\times$ hortorum). Nauka Przyroda Technologie 4(6), 98, 12 p. [in Polish with English abstract]

Wolna-Maruwka A., Gajewski P. 2011. Influence of the effective microorganisms inoculum on the dehydrogenases activity level and the number of selected soil microorganisms groups. Ecology and Technology 19(4): 214-219. [in Polish with English abstract]

Zhen Z., Liu H., Wang N., Guo L., Meng J., Ding N. et al. 2014. Effects of manure compost application on soil microbial community diversity and soil microenvironments in a temperate cropland in China. PLoS ONE 9(10), e108555, 12 p. DOI: 10.1371/journal.pone.0108555.

Research funded as part of the project "Development of a model to reduce losses of food produced by natural methods" Project ŻywNatur agreement No. IS-2/41/NCBR/2015, financed by NCBiR (2015-2017). 